\title{
ATTRACTION OF Vespula germanica WORKERS TO PROTEIN BAITS MIXED WITH INSECTICIDES
}

\author{
Tomislav Curkovic ${ }^{1 *}$, Denisse Santibáñez ${ }^{1}$, Jaime E. Araya ${ }^{1}$, Américo Contreras ${ }^{2}$ \\ ${ }^{1}$ Depto. Sanidad Vegetal, Facultad de Ciencias Agronómicas, Universidad de Chile, Casilla 1004, \\ Santiago, Chile. \\ ${ }^{2}$ Dirección Escuela de Pregrado, Facultad de Ciencias Agronómicas, Universidad de Chile, Casilla 1004, \\ Santiago, Chile. \\ * Corresponding author E-mail: tcurkovi@uchile.cl
}

\begin{abstract}
Vespula germanica F. (Hymenoptera: Vespidae) is an important pest that severely affects agriculture, tourism, beekeeping, and other activities in Chile. The objective of this study was to develop a bait for adults to be either attracted/ killed inside the trap or collected by workers, and also to serve as food for larvae (via trophallaxis) in the nest. A blood and bone flour (BBF) bait mixed with several insecticides was evaluated to trap workers in a conservation area in the Metropolitan Region, Chile, based on attractiveness to $V$. germanica and selectivity to Apis mellifera $L$. The insecticides used were abamectin (Vertimec 018 EC), fipronil (Regent 250 FS), imidacloprid (Confidor 350 SC), spinosad (Success 48), and triflumuron (Alsystin $480 \mathrm{SC}$ ). The BBF bait for V. germanica workers was not affected by the presence of insecticide at a low concentration (for most compounds it was used the previously estimated $\mathrm{LC}_{90}$ for larvae), which means that the bait mixture can attract/control populations without the risk of true repellency. Criteria such as cost, lasting effect and mode of action should be considered when selecting insecticides. The use of imidacloprid was the best choice for trapping workers, whereas fipronil and triflumuron worked better for baits targeting larvae in the colony. Food baits for V. germanica should be further optimized and tested during the spring and early summer to control populations. This species needs to be controlled before it reaches maximum densities, including queens at the time when actively forage for food during early spring.
\end{abstract}

Key words: Insecticides, non-repellency, yellowjacket, wasp baits, wasp trapping.

\section{INTRODUCTION}

Vespula germanica (F.) (Hymenoptera: Vespidae) was probably introduced in Chile in the early 1970s and first reported in central Chile by Peña et al. (1975). It is currently found from Atacama $\left(\sim 27^{\circ} \mathrm{S}, 70^{\circ} \mathrm{W}\right)$ to Magallanes $\left(\sim 54^{\circ} \mathrm{S}, 70^{\circ} \mathrm{W}\right)$ (Estay et al., 2008; Sola et al., 2015), and it is considered a serious pest (Chiappa et al., 1986; Estay et al., 2008) that severely affects agriculture, particularly vineyards, e.g. losses in Chile reach up to $10 \%$ in some years and areas (Curkovic et al., 2004; Ripa,
2004; Estay et al., 2008). Vespula germanica also affects apiaries and the tourism sector (Estay et al., 2008). Recently, losses caused by $V$. germanica were estimated above US\$ 21 million/year in the country, considering the impact on fruit orchards, wine production, and biodiversity (MMA, 2017). Therefore, mechanisms to control this wasp need to be developed and implemented. The use of animal protein as baits for traps has been studied on V. germanica (Estay et al., 2008; Curkovic et al., 2017). Efficient attractants need to be selective (Curkovic et al., 2017) and powerful in order to

Received: 20 March 2018. $\quad$ Accepted: 23 July 2018. 
attract large numbers of workers (Day and Jeanne 2001). Besides, it is possible to prepare toxic baits (mixed with insecticides) to either destroy adults (workers, queens, males) visiting a trap, or affect the colony when they return inside the nest (Estay et al., 2008).

This approach might work using the key feature of trophallaxis behavior in which workers provide larvae with protein foods, mostly chewed insects and spiders, and also meat of dead animals (Magunacelaya et al., 1986, Ripa, 2004). Nevertheless, as insecticides might act as repellents in this type of mixtures (Estay et al., 2008), non-repellent compounds need to be identified. Repellency might act by preventing an insect to approach (true repellency) or elicit behavioral responses to move away from a source after exposure (excito-repellency) (Curkovic and Brunner, 2006).

The present study reports on the potential use of a protein toxic bait mixed with synthetic insecticides at low concentration levels (in most cases the $\mathrm{LC}_{90}$ estimated for larvae) to control $\mathrm{V}$. germanica in the field.

\section{MATERIALS AND METHODS}

Study location. The study was conducted in "Quebrada de la Plata" (3329' S; 7053 W), a 1,100 ha conservation area at "Rinconada de Maipú"' Experimental Station, University of Chile, Metropolitan Region, Chile, which was recently declared a Sanctuary by the Ministry of Environment of Chile (UCH, 2017). This is a wild and semi-mountainous creek area, dominated by xeric schrub and sclerophyll trees (Gajardo, 1994). In this area, $V$. germanica presents large populations (Curkovic et al., 2017). Four sites spaced approx. 50-100 m apart were used.

Bait and insecticides. The selected attracting feeding bait was blood and bone flour (BBF), which is a by-product of the meat industry containing $20 \%$ protein, $22 \% \mathrm{Ca}$, and $11 \% \mathrm{P}$ (Estay et al. (2008). Al-Antary et al. (2016) and Curkovic et al. (2017) have described meat as a highly efficient product in baits against $V$. germanica and $V$. orientalis (L.). The by-product above mentioned was chosen based on both attractiveness to $V$. germanica and selectivity to Apis mellifera L. (Curkovic et al., 2017). Active ingredients (a.i.) of insecticides used were (commercial names and formulations are indicated in parentheses): abamectin (Vertimec 018 EC); fipronil (Regent 250 FS); imidacloprid (Confidor 350 SC); spinosad (Success 48); and triflumuron (Alsystin 480 SC). The amounts of insecticides added to the mixtures were based on the $\mathrm{LC}_{90}$ value estimated by Ulloa (2005) for larvae fed with honey solutions. The $\mathrm{LC}_{90}$ value of imidacloprid was not available at the time of the experiment. Mixtures were prepared immediately before placing the traps in the field. The control consisted of a whole trap except for the insecticide, with no feeding bait. The amounts and combinations evaluated are presented in Table 1.

Traps and setting. Traps consisted of 2 L transparent plastic bottles with openings in the middle and detergent solution on the bottom (Curkovic et al., 2017). All traps were set on the same day (February $9^{\text {th }}$ ). They were placed at $\sim 1.5$ $\mathrm{m}$ above the ground on trees and shrubs present at the site. The day before setting the experiment, the foragers flying in each place were roughly estimated, identifying a gradient in $V$. germanica population from $\sim 1$ up to $\sim 10$ wasp $\cdot \mathrm{min}^{-1}$ over the vegetation (in a $\sim 100 \mathrm{~m}$ transect in each plot), on the four blocks (as described by Curkovic et al., 2017). Distance between traps was at least $20 \mathrm{~m}$ on each place.

Trap service and insect identification. Field work was done Monday through Friday; visits were recorded from February $10^{\text {th }}$, while captures

Table 1. Treatments, insecticides, and bait volumes used/trap for V. germanica trapping.

\begin{tabular}{llrl}
\hline Treatments & Insecticides $\left(\right.$ g a.i. $\left.\mathbf{~ L}^{-1} \mathbf{c} . \mathbf{p}.\right)$ & LC $_{\mathbf{9 0}}{ }^{2}$ & BBF + C.P. $(\mathbf{m L})$ \\
\hline BBF+A (abamectin) & Vertimec 018 EC $(18 \mathrm{~g})$ & 25.33 & $60+0.0003$ \\
BBF+F (fipronil) & Regent 250 FS (250 g) & 40.00 & $60+0.0060$ \\
BBF+I (imidacloprid) & Confidor 350 SC $(350 \mathrm{~g})$ & $\mathrm{n} / \mathrm{d} 3$ & $60+0.02524$ \\
BBF+S (spinosad) & Success 480 SC $(442 \mathrm{~g})$ & 1.81 & $60+0.0005$ \\
BBF+T (triflumuron) & Alsystin 480 SC $(480 \mathrm{~g})$ & 1031.25 & $60+0.2970$ \\
BBF (Blank) & BBF alone & $\mathrm{n} / \mathrm{a}$ & $60+0.00$ \\
Control & Neither BBF nor insecticide & --- & --- \\
\hline
\end{tabular}

BBF: Blood and bone flour.

c.p.: commercial product; ${ }^{2}$ Larval $\mathrm{LC}_{90}$ (mg. a.i. $\mathrm{L}^{-1}$ ), from Ulloa (2005); ${ }^{3}$--: No data available; Confidor rate recommended by supplier. 
were recorded from February $16^{\text {th }}$. All trap service ended on March $9^{\text {th }}$ that corresponds to a period of the year with high $V$. germanica activity in the area. Traps were rotated clockwise after each service to minimize the effect of their location within each block (Landolt, 1998). Visits (insects approaching a trap opening) were recorded as described by Curkovic et al. (2017) during a 3-min period of observation per trap. Afterwards, V. germanica were collected by sieving the detergent solution. The volume of detergent solution in the traps was $\sim 200 \mathrm{~mL}$. The baits were replaced each Friday. The study ended after two and half (captures) and three (visits) complete trap rotations within blocks. Collected insects were identified under 20x magnification.

Experiment design and data analysis. A randomized complete block design was used, with seven treatments, four replicates, and 1 trap per experiment unit. Captures and visits of individuals per trap were analyzed with a generalized linear mixed model, using the negative binomial distribution and log link function through the lme4 package (Bates et al., 2015). The seven treatments evaluated were included as a fixed effect, and the blocks as a random effect. The mean values per treatment were obtained through the application of the inverse link function of linear predictors, while their standard errors were calculated through the Delta Method (Agresti, 2013). Wald test was used to verify differences between treatments through car package (Fox and Weisberg, 2011). Significant differences between means were determined using the Tukey test for multiple comparisons through the lsmeans (Lenth, 2016) and multcompView (Graves et al., 2015) packages. All the analyses were done using the $\mathrm{R}$ programming language (R Core Team, 2017).

\section{RESULTS AND DISCUSSION}

All treatments (baits) captured workers (a total of 4,808$)$ and males (106) of V. germanica. No queens were trapped during the period evaluated. Workers were captured the whole period (February $10^{\text {th }}$ through March $10^{\text {th }}$ ), whereas males catches started on March $1^{\text {st }}$. Visits were $924 \mathrm{~V}$. germanica. Significant differences between treatments were verified using the Wald test for workers (Chisq $=35.681$; $p$-value $<3.179 \mathrm{e}$ 06), males $($ Chisq $=14,286$; $p$-value $=0.0266)$, total (workers and males, Chisq $=38.303$; $\mathrm{p}$-value $=9.8 \mathrm{e}-$ 07 ), and visits (Chisq $=142.12$; $\mathrm{p}$-value $<2.2 \mathrm{e}-16$ ). Mean values adjusted to the model per treatment are presented in Table 2. Significant differences were found between the control and the rest of the treatments in terms of workers, total workers + males and visits. No statistical differences were observed between the control treatment, $\mathrm{BBF}+\mathrm{I}$, and $\mathrm{BBF}+\mathrm{A}$ only in male captures.

No significant differences were observed for captures between treatments including insecticides and the blank (same set up, including the bait, except for the absence of insecticide). In general, treatments including the protein bait were significantly more attractive than the control (no bait). The average captures of workers/trap/reading ranged between 11.52 and 15.17 among insecticide treatments, whereas the blank caught 9.68 and the control 5.68. Regarding males, average captures/trap/reading were much smaller, ranging between 0.183 and 0.35 among insecticide treatments, whereas the blank caught 0.25 , and the control 0.083 . In this sense, low catches may account for a lower statistical discrimination between treatments. These results suggest no true repellency, i.e. the impediment for insects to approach the source (bait) (Curkovic

Table 2. V. germanica captures and visits per treatment (mean/trap \pm Standard Error).

\begin{tabular}{lccrr}
\hline & \multicolumn{3}{c}{ Trap captures } & Wasp \\
\cline { 2 - 4 } Treatments & \multicolumn{1}{c}{ Workers } & Males & \multicolumn{1}{c}{ Total } & \multicolumn{1}{c}{ visits } \\
\hline Control & $70.2 \pm 19.4 \mathrm{a}$ & $0.7 \pm 0.5 \mathrm{a}$ & $70.6 \pm 19.6 \mathrm{a}$ & $5.3 \pm 1.4 \mathrm{a}$ \\
$\mathrm{BBF}$ & $132.8 \pm 36.4 \mathrm{~b}$ & $2.2 \pm 1.4 \mathrm{ab}$ & $136.1 \pm 37.3 \mathrm{~b}$ & $30.2 \pm 7.0 \mathrm{~b}$ \\
$\mathrm{BBF}+\mathrm{T}$ & $158.7 \pm 43.3 \mathrm{~b}$ & $2.8 \pm 1.7 \mathrm{~b}$ & $162.7 \pm 44.4 \mathrm{~b}$ & $34.2 \pm 7.9 \mathrm{~b}$ \\
$\mathrm{BBF}+\mathrm{I}$ & $168.3 \pm 46.0 \mathrm{~b}$ & $2.2 \pm 1.4 \mathrm{ab}$ & $171.6 \pm 46.9 \mathrm{~b}$ & $34.9 \pm 8.0 \mathrm{~b}$ \\
$\mathrm{BBF}+\mathrm{S}$ & $168.8 \pm 46.1 \mathrm{~b}$ & $3.0 \pm 1.8 \mathrm{~b}$ & $174.0 \pm 47.5 \mathrm{~b}$ & $30.2 \pm 7.0 \mathrm{~b}$ \\
$\mathrm{BBF}+\mathrm{A}$ & $172.8 \pm 47.1 \mathrm{~b}$ & $1.6 \pm 1.0 \mathrm{ab}$ & $175.6 \pm 47.9 \mathrm{~b}$ & $30.7 \pm 7.1 \mathrm{~b}$ \\
$\mathrm{BBF}+\mathrm{F}$ & $192.8 \pm 52.5 \mathrm{~b}$ & $3.1 \pm 1.9 \mathrm{ab}$ & $197.7 \pm 53.9 \mathrm{~b}$ & $39.8 \pm 9.1 \mathrm{~b}$ \\
\hline
\end{tabular}

BBF: Blood and bone flour; T: triflumuron; I: imidacloprid; S: spinosad; A: abamectin; F: fibropanil. Means in a column with the same letter are not significantly different, according to Tukey test $(\mathrm{p}<0.05)$. 
and Brunner, 2006) occurred at the concentration levels tested. There is no information on the response of foragers after the contact with the bait, so excito-repellency was not evaluated herein. Data agree with those from Wood et al. (2006) who described that the addition of insecticide would not change the relative wasp preference for protein baits. Therefore, all five insecticides tested in this study can be potentially used as toxic baits. However, the selection of an insecticide to be mixed with toxic baits should be based on factors such as target, lasting effect, conservation and mode of action (Sackmann et al., 2001; Estay et al., 2008; Beggs et al., 2011).

Several reports addressed the use of baits plus insecticides for Vespidae (Harris and Etheridge 2001; Sackmann and Corley 2007; Hanna et al., 2012), frequently including insecticides as chlorpyrifos, diazinon, fipronil, permethrin, triflumuron, etc., but only a few reports tested imidacloprid (where wasps were confined, thus set up is not fully comparable), spinosad, or abamectin (Al-Heyari et al., 2016; Kishi and Goka, 2017). Based on the $\mathrm{LC}_{50}$ value reported for workers (Estay et al., 2008), fipronil (28 $\left.\mathrm{mg} \mathrm{L}^{-1}\right)$ seems to be the best choice if the toxic bait targets larvae in the nest. This means that the adults need to survive to the bait exposure so as to transport the bait to the nest, and feed larvae with it. In fact, fipronil has been tested in field trials using toxic baits against $V$. germanica (Harris and Etheridge, 2001; Estay et al., 2008). Abamectin is the second best choice for baits against larvae $\left(2.03 \mathrm{mg} \mathrm{L}^{-1}\right)$, followed by spinosad $\left(1.61 \mathrm{mg} \mathrm{L}^{-1}\right)$. All these three insecticides are neurotoxic compounds used in different types of baits (Harris and Etheridge, 2001; Sackmann and Corley, 2007; Rust and Su, 2012). On the other hand, if the bait targets adult wasps reaching the trap (workers, queens, or males), the best choice is imidacloprid because it is not repellent and highly toxic for workers $\left(\mathrm{LC}_{50}=0.02 \mathrm{mg} \mathrm{L}^{-1}\right)$, queens $\left(0.28 \mathrm{mg} \mathrm{L}^{-1}\right)$, and males (0.69 $\left.\mathrm{mg} \mathrm{L}^{-1}\right)$ (Estay et al., 2008). Regarding triflumuron, just based on its mode of action and uses in insect baits (insecticide growth regulator; Rust and $\mathrm{Su}, 2012$ ), it is not an alternative for baits targeting adults, but it is for those targeting larvae, and in fact, it has also been used to control $V$. germanica (Estay et al., 2008).

Declines in Vespula spp. populations resulting from the use of baits in the field have been measured by either counting wasps approaching feeding stations, nest traffic density, etc., after placing toxic baits for a period of time. Values above $70 \%$ are common on some reports (Sackmann and Corley, 2007), and even reach 9095\% (Kitt and Hopkins, 1996; Harris and Etheridge, 2001). Since methodologies and number of baits $\mathrm{ha}^{-1}$ are very variable, these results cannot be compared to those obtained in this study (but see discussion on visits). It is important to consider that the insecticide concentration in baits was $\mathrm{LC}_{90}$ for larvae, which tends to be greater for adults (i.e. adults are more tolerant, requiring greater concentrations to be killed; Estay et al., 2008). Therefore, it was assumed that some wasps approaching the trap would collect the bait and return to the nest, affecting the colony. However, as the main objective was to identify insecticides not causing repellence for the development of toxic baits, no long-term efficacy was assessed.

Visits were higher than those observed for three types of baits (BBF, condensed milk, and raspberry jam) + acetic acid and isobutanol in a similar field test conducted by Curkovic et al. (2017), who recorded 466 visits. The present study recorded 924 visits even though it included fewer treatments (7 against 12), and had a relatively lower amount of readings considering the same frequency (15 vs. 24$)$. Visits ranged from 2.27 to 2.98 in insecticide baits, whereas the blank had an average of 2.27 and the control only 0.4 visits/trap/reading. As most factors are the same, the amount of bait used herein (60 $\mathrm{mL}$ ) might explain a higher number of visits; a volume of $26 \mathrm{~mL}$ was previously used by Curkovic et al. (2017). The trend on visits follow the one observed for captures, so the previous discussion also applies here. Visits might serve as a measurement on $V$. germanica populations when this type of bait is used in the field. These data suggest the baits tested had a slight effect on $V$. germanica population. However, further studies are required to test this hypothesis.

\section{CONCLUSIONS}

The use of blood and bone flour (BBF) as bait for $V$. germanica workers was not affected by the presence of insecticide at a low concentration $\left(\mathrm{LC}_{90}\right.$ value was previously estimated for larvae), indicating that the bait mixture can control populations without the risk of true repellency. Since this bait was considered selective to $A$. mellifera, it should be safe for use in the field. The selection of a particular insecticide should consider factors such as cost, lasting effect and mode of action. The results obtained in this study showed that imidacloprid was the best choice for trapping workers, whereas fipronil and triflumuron worked better for baits targeting larvae in the colony. Food baits for $V$. germanica were evaluated during the fall. Thus, they should also be tested during the spring and early summer to optimize control of $V$. germanica populations, i.e., before they reach maximum 
densities, including queens at the time when they actively forage for food (early spring). Further studies are required to evaluate the impact of these treatments on $V$. germanica densities in the treated areas.

\section{LITERATURE CITED}

Agresti. 2013. Categorical Data Analysis. 744 p. 3rd ed. John Wiley \& Sons, Inc., Hoboken, New Jersey, USA.

Al Antary T M., B.N. Al- Heyari, and I.K. Nazer. 2016. Acceptance of the oriental wasp Vespa orientalis L. (Hymenoptera: Vespidae) to different baits. Adv. Environ. Biol. 10:9-16.

Al-Heyari B. N., T.M. Al Antary, and I. K. Nazer. 2016. Effectiveness of some insecticide mixed with a bait, and Heptyl Butrate on the oriental wasp Vespa orientalis L. (Hymenoptera: Vespidae). Adv. Environ. Biol. 10:17-25.

Bates, D., M. Maechler, B. Bolker, and S. Walker. 2015. Fitting linear mixed-effects models using lme4. J. Stat. Software 67(1):1-48.

Beggs, J.R., E.G. Brockerhoff, J.C. Corley, M. Kenis, M. Masciocchi, F. Muller, et al. 2011. Ecological effects and management of invasive alien Vespidae. Biocontrol 56(4):505526.

Chiappa, E., J.C. Magunacelaya, y H. Jopia. 1986. Observaciones sobre el nido de Vespula germanica (Fab.) (Hymenoptera: Vespidae), en la zona central de Chile. Rev. Chil. Entomol. 13:85-94.

Curkovic, T., J.E. Araya, y M.A. Guerrero. 2004. Avances en el manejo de la avispa chaqueta amarilla en Chile. Aconex 84:19-23.

Curkovic, T., and J.F. Brunner. 2006. Evaluation of permethrin for attracticide development against Choristoneura rosaceana and Pandemis pyrusana (Lepidoptera: Tortricidae) males. Crop Protect. 25:973- 976

Curkovic T., J. Vergara, J.E. Araya, and A. Contreras. 2017. Selective attraction of Vespula germanica (Hymenoptera: Vespidae) to feeding baits enhanced with isobutanol and acetic acid. Chil. J. Agric. Anim. Sci. 33(3):195-201.

Day, S.E., and R.L. Jeanne. 2001. Food volatiles as attractants for yellowjackets (Hymenoptera: Vespidae). Environ. Entomol. 30(1):157-165.

Estay, P., R. Ripa, M. Gerding, J.E. Araya, y T. Curkovic, 2008. Manejo integrado de la avispa chaqueta amarilla Vespula germanica (Fabricius) (Hymenoptera: Vespidae). 74 p. Boletín INIA 174. Instituto de Investigaciones Agropecuarias, Santiago, Chile.
Fox, J., and H.S. Weisberg. 2011. An R and S-Plus Companion to Applied Regression (SAGE, 2002), $2^{\text {nd }}$ ed. Thousand Oaks, California, USA.

Gajardo, R. 1994. La vegetación natural de Chile, clasificación y distribución geográfica. 165 p. Editorial Universitaria, Santiago, Chile.

Graves, S., H.P. Piepho, L. Selzer, and D.R. Sundar. 2015. MultcompView: visualizations of paired comparisons. $\mathrm{R}$ package version 0.1-7. Available at https://CRAN.R-project. org/package=multcompView (Accessed 15 January 2018)

Hanna, C., D. Foote, and C. Kremen. 2012. Shortand long-term control of Vespula pensylvanica in Hawai by fipronil baiting. Pest Manag. Sci. 68:1026-1033.

Harris, R.J., and N.D. Etheridge. 2001. Comparison of baits containing fipronil and sulphuramid for the control of Vespula wasps. New Zeal. J. Zool. 28:39-48.

Kitt, Y.T., and D.C. Hopkins. 1996. Toxic baiting of European wasp (Vespula germanica). SARDI Technical Report, Melbourne, Australia.

Kishi, S., and K. Goka. 2017. Review of the invasive yellow-legged hornet, Vespa velutina nigrithorax (Hymenoptera: Vespidae), in Japan and its possible chemical control. Appl. Entomol. Zool. 52(3):361-68.

Landolt, P.J. 1998. Chemical attractants for trapping yellowjackets Vespula germanica and Vespula pennsylvanica (Hymenoptera: Vespidae). Environ. Entomol. 27:1229-1234.

Lenth, R. 2016. Least-squares means: The $R$ package lsmeans. J. Stat. Software 69(1):1-33.

Magunacelaya, J.C., E. Chiappa, H. Toro, y R. Jubal. 1986. Observaciones sobre comportamiento y alimentación de Vespula germanica (Hymenoptera: Vespidae) en la zona central de Chile. Rev. Chil. Entomol. 14:87-93.

MMA. 2017. Valoración económica del impacto de siete especies exóticas invasoras sobre los sectores productivos y la biodiversidad en Chile. Publicación en base a la Consultoría "Valoración económica del impacto de un grupo de especies exóticas invasoras sobre la biodiversidad en Chile", en el marco del Proyecto GEF/MMA/PNUD Especies Exóticas Invasoras. 24 p. Ministerio del Medio Ambiente (MMA), Santiago, Chile.

Peña, L.E., R. Pérez de Arce, y L. Cartagena. 1975. La presencia de Vespula maculifrons (Buysson) (Hymenoptera: Vespidae) en Chile. Rev. Chil. Entomol. 9:167-168. 
R Core Team. 2017.R:A language and environment for statistical computing. R Foundation for Statistical Computing, Vienna. Rev. 26 Dec. 2017 Available at http://www.r-project.org/ (Accessed 26 December 2017)

Ripa, R. 2004. Vespula germanica: Chaqueta amarilla. Tierra Adentro 54:32-35.

Rust, M.K., and N.Y. Su. 2012. Managing social insects of urban importance. Ann. Rev. Entomol. 57:355-375.

Sackmann, P., M. Rabinovich, and J.C. Corley. 2001. Successful removal of German yellowjackets (Hymenoptera: Vespidae) by toxic baiting. J. Econ. Entomol. 94(4):811-816.

Sackmann, P., and J.C. Corley. 2007. Control of Vespula germanica (Hymenoptera, Vespidae) populations using toxic baits: bait attractiveness and pesticide efficacy. J. Appl, Entomol. 131:630-636.

Sola, F., A. Valenzuela, C. Andersoni, G. Martínez, y M. Lencinas. 2015. Reciente invasión del Archipiélago de Tierra del Fuego por la avispa Vespula germanica (Hymenoptera: Vespidae). Rev. Soc. Entomol. Arg. 74:197-202.
UCH. 2017. Inauguraron nuevo Santuario de la Naturaleza en Quebrada de La Plata. Nota Sitio Web, Universidad de Chile. Disponible en www.uchile.cl/noticias/137869/ inauguraron-nuevo-santuario-de-lanaturaleza-en-quebrada-de-la-plata (Consulta 15 de enero de 2018)

Ulloa, A. 2005. Determinación de la $\mathrm{CL}_{50}$ oral para cinco insecticidas en larvas de Vespula germanica (F.) en laboratorio. 39 p. Memoria Ing. Agrónomo. Universidad de Chile, Facultad de Cs. Agronómicas, Santiago, Chile.

Wood, G.M., D.C. Hopkins, and N.A. Schellhorn. 2006. Preference by Vespula germanica (Hymenoptera: Vespidae) for processed meats: implications for toxic baiting. J. Econ. Entomol. 99(2):263-267. 